\title{
PENINGKATAN PEMAHAMAN CARA BERWUDHU MELALUI PENERAPAN METODE DEMONSTRASI DAN SIMULASI DI SEKOLAH DASAR
}

\author{
Sucipto \\ SDN Sumberrejo 02 Kecamatan Gedangan Kabupaten Malang \\ Email sucipto1966@ymail.com
}

\section{Tersedia Online di}

http://www.jurnal.unublitar.ac.id/ index.php/briliant

\begin{tabular}{l} 
Sejarah Artikel \\
\hline Diterima pada 2 Januari 2017 \\
Disetuji pada 20 Januari 2017 \\
Dipublikasikan pada 1 Februari \\
2017 Hal. 25 - 31 \\
\hline
\end{tabular}

Kata Kunci:

cara berwudhu, demonstrasi, simulasi

\begin{abstract}
Abstrak: Rendahnya aktifitas belajar siswa tampak dari rendahnya interaksi siswa saat proses belajar mengajar, rendahnya kemampuan siswa dalam bertanya dan menjawab. Salah satu upaya dalam mengatasi permasalahan tersebut adalah dengan menerapkan pembelajaran metode demontrasi dan simulasi. Metode demonstrasi adalah suatu strategi pengembangan dengan cara memberikan pengalaman belajar melalui perbuatan melihat dan mendengarkan diikuti dengan meniru pekerjaan yang didemonstrasikan. Metode simulasi dapat diartikan sebagai cara penyajian pengalaman belajar dengan menggunakan situasi tiruan untuk memahami tentang konsep, prinsip, atau ketrampilan tertentu. Penerapan pembelajaran dengan menggunakan metode demostrasi dan simulasi dapat meningkatkan pemahaman siswa terhadap cara berwudhu yang benar.
\end{abstract}

Dalam rangka pembaharuan sistem pendidikan Nasional telah ditetapkan Visi, Misi dan strategi pembangunan pendidikan Nasional, visi pendidikan nasional yang kuat adalah terwujud sistem pendidikan sebagai pranata sosial yang kuat dan berwibawa untuk memberdayakan semua warga negara Indonesia berkembang menjadi manusia yang berkualitas sehingga mampu dan proaktif menjawab tantangan zaman yang selalu berubah

Guru memiliki peranan yang sangat penting dalam menentukan kualitas Pembelajaran yang dilaksanakan di kelas. Oleh sebab itu, guru dituntut untuk senantiasa meningkatkan kualitas pembelajaran yang dilakukan terutama didalam mempersiapkan perencanaan pembelajaran.

Hal ini menuntut adanya perubahan-perubahan pada guru terutama dalam mengorganisasikan kelas, memilih metode mengajar yang tepat, strategi belajar mengajar, maupun sikap dan karakteristik guru dalam mengelola proses belajar mengajar. Guru adalah orang yang berperan sebagai pengelola proses belajarmengajar, bertindak sebagai fasilitor yang berusaha mencipatakan kondisi belajar mengajar yang efektif, sehingga memungkinkan terjadinya proses belajar dengan baik, dan meningkatkan kemampuan siswa untuk menyimak pelajaran dan menguasai tujuan pendidikan yang harus mereka capai. Untuk memenuhi hal tersebut di atas, guru dituntut mampu mengelola proses belajar mengajar untuk 
memberikan rangsangan kepada siswa terutama pada pelajaran pendidikan agama islam, karena pelajaran terebut bukan hanya menuntut siswa kompeten dalam ranah kognitif saja namun siswa juga dituntut dapat kompeten pada ranah afektif dan psikomotorik, sehingga siswa diharapkan dapat mengaplikasikan ketiga ranah tersebut dalam pelaksanaan ibadah sehari-hari.

Oleh sebab itu Pembelajaran pendidikan agama islam khususnya pada materi wudhu melalui metode demonstrasi dan Simulasi diharapakan dapat meningkatkan kemampuan siswa berwudhu untuk dipraktekkan dalam kehidupan sehari-hari

Di dalam proses belajar mengajar guru harus memiliki strategi agar siswa dapat belajar secara efektif dan efisien, mengena pada tujuan yang diharapkan. Salah satu langkah untuk memiliki strategi itu ialah harus menguasai teknik penyajian atau biasa disebut metode mengajar. Dengan demikian, metode mengajar adalah strategi pengajaran sebagai alat untuk mencapai tujuan yang diharapkan (Roestiyah;2001).

Dalam mengajar, guru jarang sekali menggunakan satu metode, karena mereka menyadari bahwa semua metode ada kebaikan dan kelemahannya. Namun ada metode yang tepat dan ada yang kurang tepat dipergunakan. Jadi yang dipentingkan oleh guru dalam memilih metode mengajar adalah ketepatannya sebagai alat untuk mencapai tujuan. Penggunaan metode mengajar harus diarahkan pada tumbuhnya aktivitas belajar siswa yang optimal, bukan dominasi aktivitas guru. Metode mengajar bukan tujuan tapi alat untuk mencapai tujuan (Sudjana; 2002).

\section{PEMBAHASAN \\ Metode Demonstrasi}

Metode demonstrasi adalah pertunjukan tentang proses terjadinya suatu peristiwa atau benda sampai pada penampilan tingkah laku yang dicontohkan agar dapat diketahui dan dipahami oleh peserta didik secara nyata atau tiruan (Bahri, 2002:210). Metode demonstrasi adalah Metode mengajar dengan cara memperagakan barang, kejadian, aturan, dan urutan melakukan suatu kegiatan, baik secara langsung maupun melalui penggunaan media pengajaran yang relevan dengan pokok bahasan atau materi yang sedang disajikan. Dengan metode demonstrasi peserta didik berkesempatan mengembangkan kemampuan mengamati segala benda yang sedang terlibat dalam proses serta dapat mengambil kesimpulan-kesimpulan yang diharapkan. Metode demonstrasi adalah adalah cara penyajian pelajaran dengan meragakan atau mempertunjukkan kepada siswa suatu proses, situasi, atau benda tertentu yang sedang dipelajari, baik sebenarnya ataupun tiruan yang sering disertai dengan penjelasan lisan (Djamarah, 2002). Dengan metode demonstrasi, proses penerimaan siswa terhadap pelajaran akan lebih berkesan secara mendalam sehingga membentuk pengertian dengan baik dan sempurna. Juga siswa dapat mengamati dan memperhatikan selama pelajaran berlangsung.

Dengan demikian maka metode demonstrasi baik digunakan untuk mendapatkan gambaran yang lebih jelas tentang hal-hal yang berhubungan dengan proses mengatur sesuatu, proses membuat sesuatu, proes bekerjanya sesuatu, 
proses mengerjakan atau menggunakannya, komponen-komponen yang membentuk sesuatu, membandingkan sesuatu cara dengan cara lain, dan untuk mengetahui atau melihat kebenaran sesuatu. Dengan demikian dapat disimpulkan bahwa metode demonstrasi adalah suatu metode mengajar dimana seorang guru atau orang lain bahkan murid sendiri memperlihatkan kepada seluruh kelas tentang suatu proses melakukan atau jalannya suatu proses perbuatan tertentu.

\section{Tujuan Metode Demonstrasi}

Tujuan pelaksanan pembelajaran dengan menggunakan metode demonstrasi secara spisifik adalah untuk memperlihatkan proses terjadinya suatu peristiwa sesuai materi ajar, cara penyampaiannya dan kemudahan untuk dipahami oleh siswa dalam pengajaran di kelas.

\section{Kelebihan Metode Demonstrasi}

Beberapa kelebihan dari metode demontrasi adalah 1) Terjadinya verbalisme akan dihindari, siswa disuruh langsung memperhatikan bahan pelajaran yang dijelaskan 2) Proses pembelajaran akan lebih menarik 3) Siswa akan memiliki kesempatan untuk membandingkan antara teori dengan kenyataan 4) Perhatian siswa dapat dipusatkan pada hal-hal yang dianggap penting oleh guru sehingga hal yang penting itu dapat diamati secara teliti, disamping itu perhatian siswapun lebih mudah dipusatkan kepada kegiatan proses belajar mengajar dan tidak kepada teman yang lain 5) Dapat mengurangi kesalahan bila dibandingkan dengan siswa hanya membaca dan mendengarkan karena dengan didemontrasikan siswa akan mendapatkan gambaran yang jelas

\section{Kelemahan Metode Demonstrasi}

Beberapa kelemahan dari metode demonstrasi adalah 1) Memerlukan ketrampilan guru secara khusus 2) Memerlukan waktu yang banyak 3) Memerlukan kematangan dalam perancangan atau persiapan 4) Bila peserta didik tidak aktif, metode demonstrasi tidak efektif

\section{Langkah-langkah Metode Demonstrasi}

Berikut ini adalah langkah-langkah pembelajaran melalui metode demonstrasi: 1) Guru menyampaikan kompetensi yang ingin dicapai 2) Guru menyajikan gambaran sekilas materi yang akan disampaikan 3) Menyiapkan bahan/alat yang diperlukan 4) Menunjuk salah seorang siswa untuk mendemonstrasikan sesuai skenario yang telah disiapkan 5) Seluruh siswa memperhatikan demonstrasi dan menganalisanya 6) Tiap siswa mengemukakan hasil analisanya dan juga pengalaman siswa didemonstrasikan 7) Guru membuat kesimpulan.

\section{Metode Simulasi}

Metode Simulasi adalah cuplikan suatu situasi kehidupan nyata yang diangkat kedalam kegiatan pembelajaran. (Sudjana, 2002:112). Beberapa buku yang menguraikan simulasi, kurang konsisten dalam menggunakan istilah simulasi. Istilah simulasi sering dipertukarkan dengan istilah game atau 
permainan. Simulasi adalah tiruan perbuatan yang hanya pura-pura. Simulasi dari kata simulate yang artinya pura-pura atau perbuatan seolah-olah; dan simulation artinya tiruan atau perbuatan yang pura-pura (Echols dan Shadily, 1975:527). Simulasi adalah sebuah replikasi atau visualisasi dari perilaku sebuah sisitem, misalnya sebuah perencanaan pendidikan, yang berjalan pada kurun waktu tertentu (Saud 2005:129 ). Jadi dapat dikatan bahwa simulasi itu adalah sebuah model yang berisi seperangkat variabel yang menampilkan ciri utama dari sistem kehidupan yang sebenarnya.

Simulasi memungkinkan keputusan-keputusan yang menentukan bagaimana ciri-ciri utama itu bisa dimodifikasi secara nyata. Metode simulasi merupakan salah satu metode pembelajaran yang dapat digunakan dalam pembelajaran kelompok. Proses pembelajaran yang menggunakan metode simulasi cenderung objeknya bukan benda atau kegiatan yang sebenarnya, melainkan kegiatan mengajar yang bersifat pura-pura. Kegiatan simulasi dapat dilakukan oleh siswa pada kelas tinggi di sekolah dasar. Dalam pembelajaran yang menggunakan metode simulasi, siswa dibina kemampuannya berkaitan dengan ketrampilan berinteraksi dan komunikasi dalam kelompok. Di samping itu dalam metode simulasi siswa diajak untuk dapat bermain peran beberapa perilaku yang dianggap sesuai dengan tujuan pembelajaran.

\section{Tujuan Metode Simulasi}

Diantara tujuan metode simulasi adalah : 1) Untuk melatih ketrampilan tertentu baik yang bersifat profesional maupun bagi kehidupan sehari-hari 2) Untuk memperoleh pemahaman tentang sesuatu konsep atau prinsip 3) Untuk latihan memecahkan masalah, mengembangkan sikap, dan pemahaman terhadap orang lain 4) Untuk meningkatkan partisipasi belajar yang optimal 5) Untuk meningkatkan motivasi belajar siswa 6) Melatih anak untuk bekerja sama dalam kelompok secara efektif

\section{Manfaat Metode Simulasi}

Beberapa manfaat metode simulasi adalah: 1) Dapat meningkatkan motivasi dan perhatian terhadap topik dan belajar anak 2) Meningkatkan keterlibatan langsung dan partisipasi aktif anak dalam belajar 3) Meningkatkan kemampuan siswa dalam belajar kognitif, meliputi informasi faktual, konsep, prinsip dan ketrampilan membuat keputusan 4) Belajar siswa lebih bermakna 5) Meningkatkan afektif atau sikap anak 6) meningkatkan sikap empatik dan pemahaman adanya oerbedaan antara dirinya

\section{Bentuk-bentuk Simulasi}

Diantara bentuk-bentuk simulasi adalah: 1) Peer teaching bentuk ini dapat dikategorikan sebagai simulasi mengingat peer teaching adalah latihan mengajar yang dilakukan seorang mahasiswa dimana dia bertindak seolah-olah sebagai guru dan teman sekelasnya seolah-olah sebagai murid sekolah tertentu. Peer teaching ini banyak dipraktekan siswa disekolahcalon guru, untuk meningkatkan ketrampilan mengajarnya, sebelum mengajar siswa yang sebenarnya 2) Sosiodrama adalah salah satu bentuk simulasi, yakni suatu drama 
yang bertujuan untuk menemukan alternatif pemecahan masalah-masalah sosial yang berkembang dimasyarakat 3) Permainan simulasi ( simulasi games ) adalah dalam pembelajarannya siswa bermain peran sesuai dengan peran yang ditugaskan sebagai belajar membuat keputusan

\section{Langkah-Langkah Metode Simulasi}

Adapun langkah-langkah metode simulasi adalah 1) Pendidik bersama peserta didik memilih dan menyusun cuplikan suatu situasi kehidupan nyata. Selanjutnya pendidik mempelajari peraturan simulasi untuk menentukan fungsi, peran dan proses yang akan dilakukan. 2) Pendidik menjelaskan tujuan dan cara penggunaan tehnik simulasi. 3) Pendidik menjelaskan masalah-masalah yang ada dalam cuplikan itu, sehingga peserta didik berfikir untuk menghubungkan masalah yang diungkapkan dalam simulasi dengan masalah-masalah yang ada dalam kehidupan mereka. 4) Pendidik memilih dan memotivasi beberapa peserta untuk melakukan peran-perannya. 5) Pendidik atau salah seorang peserta didik memimpin diskusi tentang proses dan hasil simulasi. Dari metode simulasi ini diharapkan siswa dapat memahami cara berwudhu dengan benar dan mampu mempraktikan sendiri utamanya dalam kehidupan sehari-hari.

\section{Wudhu}

Wudhu berasal dari bahasa Arab yang berati bersih atau indah sedangkan menurut istilah syara' wudhu adalah membersihkan anggota badan dengan air mutlak sesuai syarat dan rukunnya untuk menghilangkan hadast kecil. (Anang Wahyudianto, Dkk, 2008:10)

Adapun dasar tentang cara berwudhu (rukunnya) adalah Al-Qur'an dan terjemahannya. Departemen Agama RI; 2007:206) yang artinya sebagai berikut: Hai orang-orang yang beriman jika kamu hendak mendirikan shalat maka basuhlah mukamu dan kedua tanganmu sampai siku-siku dan sapulah sebagian kepalamu dan basuhlah kedua kakimu sampai dengan kedua mata kakimu (QS. Al-Maidah:6).

\section{Syarat Wudhu}

Syarat-syarat wudhu ada lima, ilmu tentang syarat wudhu sangat penting dan wajib bagi seorang muslim untuk mengetahuinya, dikarenakan tidak syah wudhu seseorang jika tidak memenuhi semua syaratnya wudhu. Jika wudhu seseoarang tidak syah maka shalatnya pun juga tidak syah. Adapun syarat-syarat wudhu adalah: (1) Islam maka tidak sya wudhunya orang kafir atau orang yang murtad (orang yang keluar dari agama islam), (2) Tamyiz yang dimaksud tamyiz adalah seseorang yang memahami dari pada percakapan atau makan sendiri, minum sendiri dan membersihkan buang hajat sendiri atau bisa membedakan antara kanan dan kiri, (3) Bersih dari darah haid dan nifas, haid adalah darah yang keluar pada waktu tertentu bagi setiap wanita yang sudah dewasa sedangkan nifas adalah darah yang keluar setelah seseorang itu melahirkan, (4) Tidak adanya sesuatupun yang mencegah air ke kulit yaitu bersihnya kulit anggota wudhu dari semisal cat kulit, (5) Menggunakan air suci dan mensucikan yaitu air yang 
digunakan adalah air bersih dari najis dan juga bukan air musta'mal ( air yang sudah dipergunakan untuk bersuci ).

\section{Rukun Wudhu}

Rukun atau fardlu dalam wudhu ada enam, wudhu sendiri memiliki banyak fungsi dan keutamaan, salah satu diantaranya adalah membersihkan diri dari hadats kecil, adapun fardunya wudhu adalah: (1) Niat, niat adalah bertujuan sesuatu yang bersamaan dengan pekerjaan dan tempat niat adalah didalam hati sedangkan melafalkannya sunnah. Dan waktunya niat didalam melaksanakan wudhu yaitu ketika membasuh bagian pertama dari wajah. (2) Membasuh muka adapun membasuh muka didalam wudhu batas-batasnya adalah secara vertikal dari tempat tumbuhnya rambut (secara normal) sampai ke dagu dan secara horizontal dari telinga ke telinga. (3) Membasuh kedua tangan adapun batasnya yaitu dari ujung jari hingga kesiku-siku sedikit (antara 4 atau 5 jari diatas siku). (4) Membasuh sebagian kepala yaitu membasuh dari pada area kepala atau rambut. (5) Membasuh kedua kaki adapun batasnya yaitu dari jari-jari kaki hingga kedua mata kaki lebih sedikit, untuk lebih baiknya hingga betis. (6) Tertib yaitu tidak mendahulukan bagian satu dengan bagian yang lain atau sesuai urutan fardlunya wudhu.

\section{Hal-hal yang Membatalkan Wudhu}

Salah satu ilmu yang wajib diketahui oleh seorang muslim adalah batalnya wudhu, adapun hal-hal yang membatalkan wudhu adalah: (1) Keluarnya sesuatu apapun dari dua jalan. Yaitu keluarnya apapun dari qubul dan dubur (dua lubang kemaluan ) kecuali mani. Walaupun yang keluar itu tidak seperti biasanya semisal keluar batu kecil, cacing atau darah. (2) Hilangnya akal, maka batal wudhu sesorang ketika akalnya atau kesadarannya hilang karena sebab tidur, gila, ayan dan mabuk. (3) Tersentuh kulit laki-laki dan perempuan yang bukan mahramnya. Yaitu laki-laki dan perempuan yang sama-sama besar/baligh. Namun tidak batal membatalkan wudhu jika menyentuh selain kulit semisal rambut, kuku, gigi dan baju. (3) Memegang kedua kemaluan manusia. Yaitu memegang kemaluan sendiri ataupun orang lain (qubul dan dubur) dengan telapak tangan atau bagian dalam jari.

\section{KESIMPULAN}

Metode demonstrasi adalah suatu strategi pengembangan dengan cara memberikan pengalaman belajar melalui perbuatan melihat dan mendengarkan diikuti dengan meniru pekerjaan yang didemonstrasikan. Dengan metode demonstrasi, proses penerimaan siswa terhadap pelajaran akan lebih terkesan secara mendalam, sehingga membentuk pengertian dengan baik dan sempurna. Metode simulasi dapat diartikan sebagai cara penyajian pengalaman belajar dengan menggunakan situasi tiruan untuk memahami tentang konsep, prinsip, atau ketrampilan tertentu. Pengalaman belajar yang diperoleh dari metode simulasi meliputi kemampuan kerja sama, komunikatif, dan menginterpretasikan suatu kejadian. Wudhu adalah mencuci atau membasuh seluruh anggota badan tertentu dengan air sebelum mengerjakan shalat ( shalat wajib maupun shalat sunah,

30 BRILLIANT: Jurnal Riset dan Konseptual Volume 2 Nomor 1, Februari 2017 
Berwudhu merupakan syarat sah shalat sehingga kita bila mengerjakan shalat tetapi tidak berwudhu terlebih dahulu maka shalat kita akan sia-sia atau tidak sah. Berdasarkan pembahsan diatas, maka dapat disimpulkan bahwa penggunaan metode demonstrasi dan simulasi pada pembelajaran pendidikan agama islam materi wudhu dapat meningkatakan kepampuan cara berwudhu siwa yang benar.

\section{SARAN}

Agar guru mata pelajaran pendidikan agama islam dapat menerapkan model pembelajaran demonstrasi dan simulasi ini pada kegiatan belajar mengajar. Pelaksanaan demonstrasi dan simulasi ini dimungkinkan menimbulkan kegaduhan, maka guru diharapkan bisa mengembalikan jalannya demonstarsi dan simulasi agar tidak mengganggu kegiatan pembelajaran kelas lain.

\section{DAFTAR PUSTAKA}

Roestiyah, 1991, Strategi Belajar Mengajar. Jakarta : Rineka Cipto

Nana Sudjana. 2002. Dasar-Dasar Proses Belajar Mengajar. Bandung : Tarsito

Djamarah, Syaiful Bahri 2008. Strategi Belajar Mengajar. Jakarta : Rineksa Cipto

Departemen Agama RI 1989, Al-Qur'an dan tarjamah, edisi refisi terbaru Semarang : Toha Putra

Pendidikan Nasional, 2003, sistem penilaian kelas SD, SMP, SMA dan SMK, Jakarta : Dirjen Dikdasmen

Team CTL. 2003. Peningkatan Mutu Madrasah Model Proyek Pengembangan Kurikulum Madarsah. Malang: Departemen Agama. 